\title{
The Relationship between of the Learning Environment and the Higher Order Thinking Skills (HOTS) among Secondary School Students
}

\author{
Mohd Saifulkhair Omar, Mohd Isha Awang
}

\begin{abstract}
Malaysia's achievements in the TIMSS (Trends in International Mathematics and Science Study) and PISA (Program International Student Assessment) from 2007 to 2015 show a decline in the mastery of science and mathematics subjects among Malaysian students internationally (Shahril Sabudin, Azlin Norhaini Mansor, Subahan Mohd Meerah \& Azliza Muhammad, 2018) [28]. Meanwhile, the science laboratory learning environment is found that can influence the student's higher order thinking skills (HOTS). This finding is supported by Mubarok, Suprapto and Adam (2018)[21] who found that the investigative activities in the laboratory would influence the HOTS. However, there are still have no any studies that been found in Malaysia on the relationship between the science laboratory learning environment and the HOTS. Therefore, this study aims to know the relationship between of the learning environment and the HOTS among secondary school students in Kuala Nerus, Terengganu by using the quantitative method. There are two sections in the questionnaire form, which are part $A$ regarding the science laboratory learning environment and part $B$ on the student's HOTS. The part $A$ uses SLEI which was developed by Fraser et al. (1992) and the part $B$ uses a set of subjective questions that was developed by the researchers. The researchers selected 89 students from two schools using a simple random sampling. The findings showed that there were a relationship between of the learning environment in the material environment and the student's HOTS. The results of the study proved that the adequacy of materials and apparatus in science labs would enhance the student's HOTS. The implications of this study enable the Ministry of Education Malaysia (MOE) to budget for the purchase of sufficient science materials and apparatus.

Keywords : learning environment, higher order thinking skills, material environment, Ministry of Education Malaysia, materials and laboratory apparatus.
\end{abstract}

\section{INTRODUCTION}

$T_{h}$ the current developments to produce people who are well-balanced and able to compete internationally (Saipolbarin Ramli, Muhammad Taufiq Abdul Ghani, Nazri

Revised Manuscript Received on January 03, 2020.

* Correspondence Author

Mohd Saifulkhair Omar*, Pursuing Ph.D, School of Education and Modern Languages, College of Arts and Sciences (CAS), Universiti Utara, Malaysia.

Mohd Isha Awang, Associate Professor, School of Education and Modern Languages, College of Arts and Sciences (CAS), Universiti Utara, Malaysia.

(C) The Authors. Published by Blue Eyes Intelligence Engineering and Sciences Publication (BEIESP). This is an open access article under the CC BY-NC-ND license (http://creativecommons.org/licenses/by-nc-nd/4.0/)
Atoh \& Taj Rijal Muhammad Romli, 2019) [27]. This has led the government to revise the country's education policy and formulate the long term plan of the Malaysian Education Development Plan (2013 - 2025) with a focus on the world-class quality education, where the main focus in the PPPM is to "provide equitable access of the quality education international standards" (Mazlini Adnan, Aminah Ayob, Tek, Mohd Nasir Ibrahim, Noriah Ishak \& Jameyah Sheriff, 2016) [20]. In order to provide our students competing internationally, the Higher Order Thinking Skills (HOTS) should be given a priority (Nur Hawa Hanis Abdullah \& Ghazali Darusalam, 2018) [23]. The international benchmarks of TIMSS and PISA will be used to assess the performance of Malaysian students (KPM, 2012) [13]. However, the Malaysia's low rankings in the test proved that the Malaysian students found the difficulties to apply HOTS (KPM, 2012) [13]. This is because the vision of the MOE for the target of 2025 is the Malaysia's position at the one third of the best world ranking in TIMMS and PISA. Therefore, the Ministry of Education Malaysia (MOE) has introduced the 21st Century Learning (21CL), "Pembelajaran Abad ke 21, PAK21" which emphasizing the HOTS in teaching and learning in the classroom.

The objective of this study is :

(a) to identify the level of science laboratory learning environment.

(b) to identify the student's level of higher order thinking skills.

(c) to identify the relationship between the science laboratory learning environment and the higher order thinking skills.

The findings showed that there were a relationship between of the learning environment in the material environment and the student's HOTS. The level of science laboratory learning environment dimension showed at the high levels which were the rule clarity (mean $=3.84)$ and the student's cohesiveness (mean $=3.63$ ). Meanwhile, the other three dimensions were at the medium level; material environment $($ mean $=3.11)$, open-endedness $($ mean $=2.91)$ and integration (mean $=2.79$ ). Futher more, the results of the HOTS dimension level showed that the analysing dimension (mean =1.67) was at the medium level. While, the other three dimensions were at the lower levels; creating (mean = 1.35), applying $($ mean $=1.05)$ and evaluating $($ mean $=1.05)$.

Published By:

Blue Eyes Intelligence Engineering \& Sciences Publication 


\section{BACKGROUND OF THE STUDY}

The 21st Century Learning (21CL) is a student-centred learning process based on the elements of communication, collaboration, critical thinking and creativity and the application of pure and ethical values (Wayan Redhana, 2019) [20]. In addition, 21CL means that the teachers use the student-centred learning methods and emphasize the elements of building HOTS within the students (Khair Mohamad Yusof, in KPM 2016) [16].

In the HOTS learning environment, teaching and learning process will change from the teacher-centred to the student-centred. The student-centred learning can stimulate student's thinking through the activities such as exploration, research and project-based learning where the teachers play a role as facilitators (KPM, 2014) [14]. This finding is supported by Mubarok, Suprapto and Adam (2018) [21] who found that the investigative activities in the laboratory would influence the HOTS. This is because the active learning already happened in the laboratory while the students were exploring (Nur Liyana Ali, Ta, Sharifah Zarina Syed Zakaria, Mazlin Mokhtar \& Sharina Abdul Halim, 2014) [24].

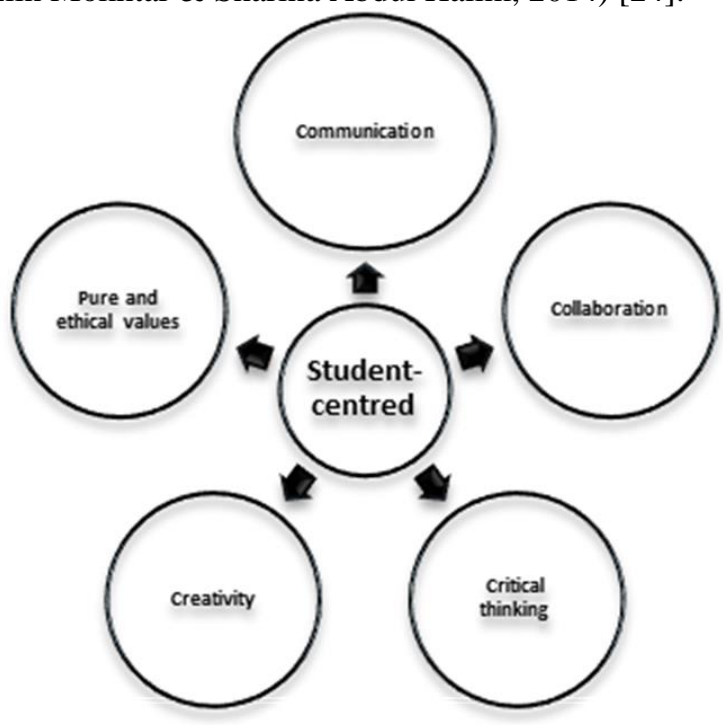

Figure 1

However, Malaysia's achievements in the TIMSS (Trends in International Mathematics and Science Study) and PISA (Program International Student Assessment) from 2007 to 2015 showed a decline in the mastery of science and mathematics subjects among Malaysian students internationally (Shahril Sabudin, Azlin Norhaini Mansor, Subahan Mohd. Meerah \& Azliza Muhammad, 2018) [28].

Drawing on the issue of the weakening of the HOTS among the Malaysian students, the elements of the science laboratory learning environment were chosen as the variable in this study. Studies abroad have found that the science laboratory learning environment will influence the HOTS students' (Akani, 2015; Hofstein, Dkeidek, Katchevitch, Nahum, Kipnis, Navon, Shore, Taitelbaum \& Mamlok-Naaman, 2019; Madhuri, Kantamreddi \& Goteti, 2012) [1][12][19].

However, the study by Arni Yuzie Mohd Arshad and Ruhizan Mohd Yasin (2015) [3] found that students' level of thinking skills were modest and still in the cognitive domain of the app. Overall, the majority of students in the cognitive domain of the application were $61 \%$, the analysis was $33 \%$, the assessment was $26 \%$ and the design was $20 \%$.
No studies have been found in Malaysia on the study of the relationship of learning environment in science laboratory to students' high level thinking skills. So, this has prompted researchers to study the relationship between the science laboratory learning environment and HOTS as they have never been able to find a study of the relationship.

\section{RESEARCH QUESTIONS}

The research questions of the study are

1. What is the level of the dimension of science laboratory learning environment in the secondary school?

2. What is the level of the dimension of higher order thinking skill (HOTS) among the secondary school students?

3. Is there a relationship between the dimension of science laboratory learning environment and the dimension of the higher order thinking skills (HOTS) among the secondary school students?

\section{METHOD}

\section{A. Research Design}

In generally, this study was correlated using a cross-sectional approach in the quantitative data collection process through respondents. A set of questionnaires was used to collect data to identify the direction and influence of the study constructs (Creswell, 2014; Bakker, 2018) [10]. The questionnaire consisted of two sections; Part A is the science laboratory learning environment and Part B is the higher order thinking skills (HOTS).

\section{B. Sampling Design}

The population of respondents was from all the form two students in the district of Kuala Nerus, Terengganu. Two secondary schools were selected by a simple random sampling. This sampling was chosen because it was suitable to use when the population almost had a uniform characteristics. This sampling was in line with the two following assumptions; (1) every member of the population has the same opportunity to choose, (2) the choice of one subject is independent and independent of the other (Azizi, Shahrin, Jamaludin, Yusof \& Abd.Rahim, 2007) [5].

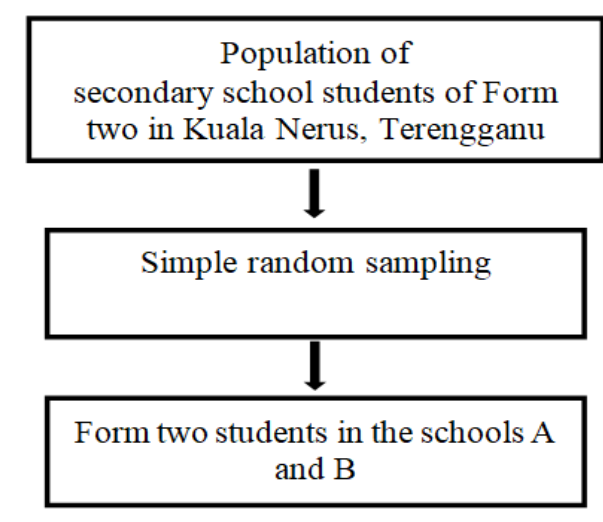

Figure 2

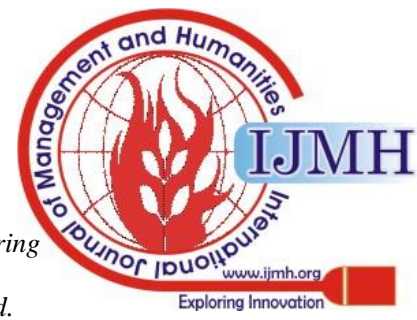




\section{Instrument}

The instrument was used in this study adapted and modified by Che Nidzam Che Ahmad (2011) [6] from the Science Laboratory Environment Inventory (SLEI) which was developed by Fraser et al. (1992). The original version of the SLEI had 35 items, presented in five different scales; student's cohesiveness, open-endedness, integration, rule clarity and material environment. Each scale in SLEI has seven items.

According to a study by Stanger-Hall (2012) [29] who found that the structured questions was better in promoting the higher order thinking skills among students. Therefore, a set of structured question instruments were developed by the researchers. The questions were adapted and modified from Form Three Assessment, "Pentaksiran Tingkatan 3, PT3" questions of 2016 and 2017 \{KPM, 2018) [17] and were based on Bloom's Taxonomy (2001). The construct verifications in the assessment were carried out by two experienced and specialised teachers from AKRAM (Angkatan Kerja Rajin dan Mulia) Terengganu. Subsequently, alpha croncbach tests were performed to determine the reliability of the instruments. There are ten structured questions, which include the subscales of applying, analysing, evaluating and creating.

\section{Alpha Croncbach}

Table 1

\begin{tabular}{|l|c|c|c|}
\hline $\begin{array}{l}\text { SLEI } \\
\text { Dimension }\end{array}$ & Item No. & $\begin{array}{c}\text { Item } \\
\text { Dropped }\end{array}$ & $\begin{array}{c}\text { Alpha } \\
\text { Cronbach } \\
\text { Value, } \boldsymbol{\alpha}\end{array}$ \\
\hline $\begin{array}{l}\text { Student's } \\
\text { cohesiveness }\end{array}$ & $1,2,3,4,5$ & $6^{*}, 7^{*}$ & 0.70 \\
\hline Open-endedness & $11,12,13$ & $\begin{array}{c}\text { 8, 9, 10, } \\
14^{*}\end{array}$ & 0.76 \\
\hline Integration & $\begin{array}{c}19^{*}, 20^{*}, \\
21^{*}\end{array}$ & $\begin{array}{c}15,16, \\
17,18^{*}\end{array}$ & 0.83 \\
\hline Rule clarity & $\begin{array}{c}22,23,24, \\
25,26\end{array}$ & $27^{*}, 28^{*}$ & 0.75 \\
\hline $\begin{array}{l}\text { Material } \\
\text { environment }\end{array}$ & $\begin{array}{c}29,30,31, \\
32^{*}, 33^{*}, \\
34^{*}, 35^{*}\end{array}$ & 29,30 & 0.74 \\
\hline
\end{tabular}

The integration dimension had a good reliability value of over 0.8 , while the other four dimensions had a sufficient reliability values for the measurement above 0.7 (Ary et al., 2002; Nunnally, 1978; Coakes, Steed \& Ong 2009) [4][22].

Table 2

\begin{tabular}{|l|c|c|}
\hline HOTS Dimension & Item No. & $\begin{array}{c}\text { Alpha Cronbach } \\
\text { Value, } \boldsymbol{\alpha}\end{array}$ \\
\hline Applying & 1,5 & 0.72 \\
\hline Analysing & 2,6 & 0.71 \\
\hline Evaluating & 3,7 & 0.77 \\
\hline Creating & 4,8 & 0.65 \\
\hline
\end{tabular}

All dimensions showed an adequate reliability values for the measurements above 0.7 , except the creating dimensions had a satisfactory reliability values above 0.6 (Ary et al., 2002; Nunnally, 1978; Coakes, Steed \& Ong 2009) [4][22]. However, some researchers recommended an alpha coefficient of 0.6 and above, especially for the preliminary studies (Fauzi Hussin, Jamal Ali \& Mohd Saifoul Zamzuri Noor, 2014) [11].

\section{E. Data Collection}

Prior to initiate the data collection process, the researchers firstly applied the permission from the Education Planning and Research Division (EPRD) (MOE) before starting the study. After obtaining the permission from Terengganu State Education Department and then from the school's principal, the researchers went to the involved schools for distributing the questionnaire to the selected respondents.

\section{F. Data Analysis}

Table 3

\begin{tabular}{|c|l|c|}
\hline No. & \multicolumn{1}{|c|}{ Research Questions } & $\begin{array}{c}\text { Type Of } \\
\text { Analysis }\end{array}$ \\
\hline 1 & $\begin{array}{l}\text { What is the level of the dimension of } \\
\text { science laboratory learning } \\
\text { environment in the secondary school? }\end{array}$ & Mean \\
\hline 2 & $\begin{array}{l}\text { What is the level of the dimension of } \\
\text { higher order thinking skill (HOTS) } \\
\text { among the secondary school students? }\end{array}$ & Mean \\
\hline 3 & $\begin{array}{l}\text { Is there a relationship between the } \\
\text { dimension of science laboratory } \\
\text { learning environment and the } \\
\text { dimension of the higher order thinking } \\
\text { skills (HOTS) among the secondary } \\
\text { school students? }\end{array}$ & $\begin{array}{l}\text { Spearman's } \\
\text { Correlation }\end{array}$ \\
\hline
\end{tabular}

The Table 3 above shows the types of analysis that will be used in this study.

The research method involves in this study are descriptive and inference data analysis to answering research questions related to the current state of the science laboratory learning environment and higher order thinking skills among form two student in Kuala Nerus, Terengganu.

\begin{tabular}{|c|c|}
\multicolumn{2}{|c|}{ Table 4 } \\
\begin{tabular}{|c|c|}
\hline Mean Score & Level \\
\hline $3.34-5.00$ & High \\
\hline $1.67-3.33$ & Medium \\
\hline $0-1.66$ & Low \\
\hline
\end{tabular}
\end{tabular}

Table 5

\begin{tabular}{|c|c|}
\hline Score & Scale \\
\hline 1 & Strongly Disagree \\
\hline 2 & Disagree \\
\hline 3 & Neither Agree or Disagree \\
\hline 4 & Agree \\
\hline 5 & Strongly Agree \\
\hline
\end{tabular}

Published By:

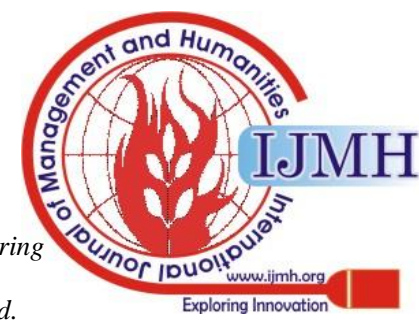


The Relationship between of the Learning Environment and the Higher Order Thinking Skills (HOTS) among Secondary School Students

\section{RESULT}

Research questions 1: What is the level of the dimension of science laboratory learning environment in the secondary school?

Table 4

\begin{tabular}{|l|c|c|}
\hline Dimension SLEI & Mean & Std. Deviation \\
\hline Student's cohesiveness & 3.63 & .54 \\
\hline Open-endedness & 2.91 & .55 \\
\hline Integration & 2.79 & .53 \\
\hline Rule clarity & 3.84 & .60 \\
\hline Material environment & 3.11 & .46 \\
\hline
\end{tabular}

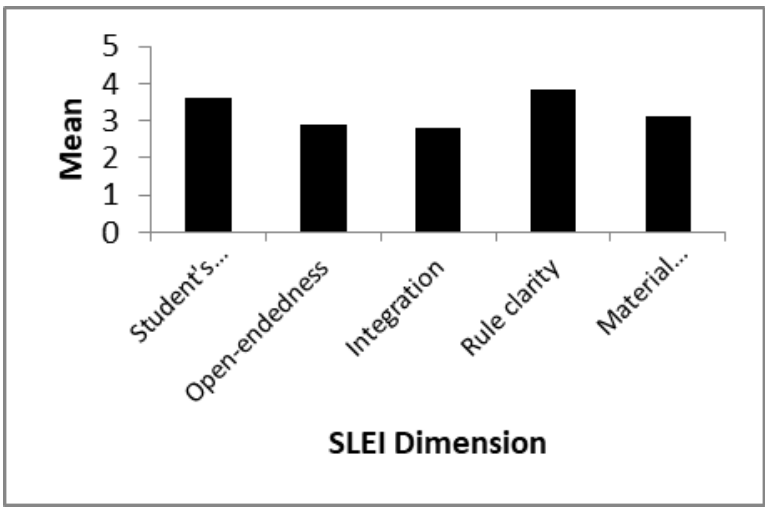

Figure 3

The results of the study for the two dimensions of SLEI showed at the high levels which are the rule clarity (mean = 3.84 ) and the student's cohesiveness (mean = 3.63). Meanwhile, the other three dimensions are at the medium level; material environment (mean $=3.11$ ), open-endedness (mean $=2.91)$ and integration (mean $=2.79$ ).

Research questions 2: What is the level of the dimension of higher order thinking skill (HOTS) among the secondary school students?

Table 5

\begin{tabular}{|l|c|c|}
\hline HOTS dimension & Mean & Std. Deviation \\
\hline Applying & 1.05 & .67 \\
\hline Analysing & 1.67 & 1.06 \\
\hline Evaluating & 1.05 & .81 \\
\hline Creating & 1.35 & .97 \\
\hline
\end{tabular}

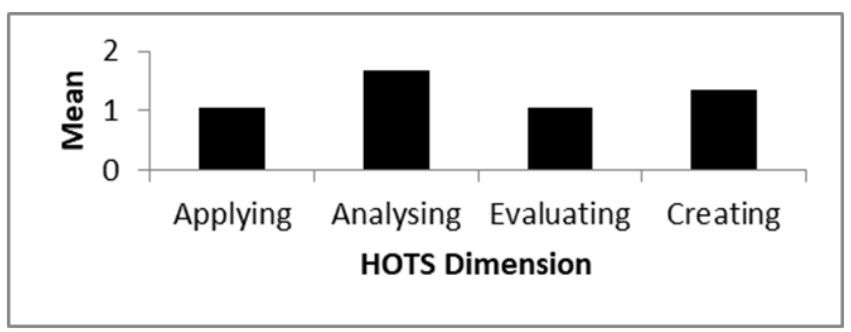

Figure 4
The results of this study showed that the analysing dimension (mean $=1.67)$ is at the medium level. Meanwhile, the other three dimensions are at the lower levels; creating (mean = $1.35)$, applying $($ mean $=1.05)$ and evaluating $($ mean $=1.05)$.

Research questions 3: Is there a relationship between the dimension of science laboratory learning environment and the dimension of the higher order thinking skills (HOTS) among the secondary school students?

Table 6

\begin{tabular}{|c|c|c|c|c|c|c|c|c|}
\hline \multirow{3}{*}{ SLEI } & \multicolumn{8}{|c|}{ HOTS } \\
\hline & \multicolumn{2}{|c|}{ Applying } & \multicolumn{2}{|c|}{ Analysing } & \multicolumn{2}{|c|}{ Evaluating } & \multicolumn{2}{|c|}{ Creating } \\
\hline & $r_{x y}$ & Sig. & $r_{x y}$ & Sig. & $r_{x y}$ & Sig. & $r_{x y}$ & Sig. \\
\hline $\begin{array}{c}\text { Student's } \\
\text { cohesivenes } \\
\text { s }\end{array}$ & .030 & $\begin{array}{c}.78 \\
2\end{array}$ & $\begin{array}{c}.257 \\
*\end{array}$ & $\begin{array}{c}.01 \\
5\end{array}$ & .059 & $\begin{array}{c}.58 \\
5\end{array}$ & .049 & $\begin{array}{c}.64 \\
6\end{array}$ \\
\hline $\begin{array}{l}\text { Open-ended } \\
\text { ness }\end{array}$ & .045 & $\begin{array}{c}.67 \\
6\end{array}$ & .043 & $\begin{array}{c}.69 \\
2\end{array}$ & .031 & $\begin{array}{c}.77 \\
6\end{array}$ & .141 & $\begin{array}{c}.18 \\
6\end{array}$ \\
\hline Integration & .040 & $\begin{array}{c}.71 \\
3 \\
\end{array}$ & .006 & $\begin{array}{c}.95 \\
9 \\
\end{array}$ & .035 & $\begin{array}{c}.74 \\
4 \\
\end{array}$ & .077 & $\begin{array}{c}.47 \\
2 \\
\end{array}$ \\
\hline Rule clarity & .080 & $\begin{array}{c}.45 \\
9 \\
\end{array}$ & .106 & $\begin{array}{c}.32 \\
4 \\
\end{array}$ & .033 & $\begin{array}{c}.76 \\
1 \\
\end{array}$ & .061 & $\begin{array}{c}.56 \\
8 \\
\end{array}$ \\
\hline $\begin{array}{l}\text { Material } \\
\text { environment }\end{array}$ & $\begin{array}{c}.235 \\
*\end{array}$ & $\begin{array}{c}.02 \\
7\end{array}$ & $\begin{array}{c}.234 \\
*\end{array}$ & $\begin{array}{c}.02 \\
7\end{array}$ & $\begin{array}{c}.262 \\
*\end{array}$ & $\begin{array}{c}.01 \\
3\end{array}$ & $\begin{array}{c}.303^{*} \\
*\end{array}$ & $\begin{array}{c}.00 \\
4\end{array}$ \\
\hline
\end{tabular}

* Significant level at 0.05

** Significant level at 0.01

There is a significant relationship between the dimensions of material environment and all the HOTS dimensions. Meanwhile, there is also a significant relationship between the dimensions of student's cohesiveness and the analysis dimension of HOTS.

\section{DISCUSSION}

The mean analysis found that the level of learning environment was moderate (mean $=3.25$ ) however Higher Order Thinking Skills were low (mean $=1.28$ ). It also was found that the dimensions of rule clarity (mean $=3.84)$ and student's cohesiveness $($ mean $=3.63)$ were high. Meanwhile, the dimensions of the material environment (mean $=3.11)$, open-endedness (mean $=2.91$ ) and integration $($ mean $=2.79$ ) were moderate. This data was supported by Pyatt and Sims (2007) [25] that noted in most of the science activities, the students were not given the opportunity to explore and create their own understanding about the phenomenon of their learning. Che Nidzam Che Ahmad, Kamisah Osman and Lilia Halim (2010) [6] suggested that the teachers could not delivered the content of the lesson alone without giving attention to the psychosocial aspects such as providing sufficient teaching materials for students to carry out investigation and giving an emphasize activities to integrate the theory learning in the classroom with the hands-on activities in the laboratory. The teachers should give the students an opportunity to generate ideas and design their own experiments.

The mean analysis for higher order thinking skills level was low. But, the analysing dimension was the highest mean (mean $=1.67)$, followed by creating $($ mean $=1.35)$ and finally applying and evaluating which were at the same mean of 1.05. This finding was in line with the studies by Tee Tze Kiong, Jailani Md Yunos, Razali Hassan, Yee Mei Heong,

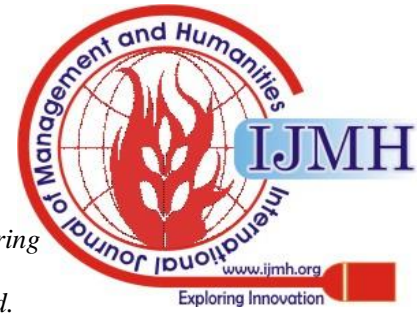


Atan Hj. Hussein, and Mimi Mohaffyza Mohamad (2012) [18] on 384 of form one students of this country who found that their level of higher order thinking skills were very low.

There was a significant relationship between the learning environment for the material environment dimension and the higher order thinking skills. This was in line with the findings of Akinbobola and Olufunminiyi (2015) [2] who found that the adequate material environment would enhance the critical skills and creativity of the students. There was also a cohesiveness and the analysis dimension of HOTS. However, the findings of Ramnarain and Hlatswayo's (2018) [26] studies on the teachers in Mpumalanga, South Africa confirmed that the laboratory facilities, the teaching materials and the time to solve the curriculum which were inadequate, as well as many students in the classroom were hindering them to teach.

\section{VII.CONCLUSION}

Overall, the results showed that the science laboratory learning environment was correlated with the higher order thinking skills of the secondary school students in Kuala Nerus, Terengganu. The material environment played an important role in enhancing student's critical skills and creativity. The adequate laboratory materials and apparatus would stimulate the student's skills, which would encourage them to innovate and creative in the science laboratory learning environment.

The teachers as a facilitators also should increase the activity in the science laboratory. The science laboratory learning environment had been proven to enhance the HOTS through the experimental activities. This finding was supported by Mubarok, Suprapto and Adam (2018) [21] who found that the investigative activities in the laboratory would influence the HOTS. Therefore, the government through the MOE must always ensure an adequate provision for the purchase of materials and laboratory apparatus in schools whether in the urban or the rural.

\section{ACKNOWLEDGMENT}

The author would like to thank the parties involved in this study. Started with the Educational Planning and Policy Research Division, the Ministry of Education, Terengganu State Education Department and the principals of the respective schools. Also not forget to the supervisor who always providing a guidance and motivation throughout my study, Associate Professor Dr Mohd Isha Awang and the entire staff of the School of Education and Modern Languages (SEML), UUM College of Arts and Sciences (CAS), Universiti Utara Malaysia (UUM) Sintok, Kedah, Malaysia. To my beloved wife Wan Kartini Wan Manan and my children who helped and understood throughout my study.

\section{REFERENCES}

1. Akani, O. (2015). Laboratory teaching: Implication on students' achievement in chemistry in secondary schools in Ebonyi State of Nigeria. Journal of Education and Practice, 6(30), 206-213.

2. Akinbobola, Akinyemi, O. (2015). Evaluating science laboratory classroom learning environment in Osun State of Nigeria for national development. Journal of Resources Development and Management, 9 14-20. relationship between the dimensions of student's

3. Arni Yuzie Mohd Arshad \& Ruhizan Mohd Yasin (2015). Kemahiran berfikir aras tinggi murid dalam konteks penyelesaian masalah bagi mata pelajaran sains. Asian Education Action Research Journal (AEARJ), 4, 81-96.

4. Ary, D., Jacobs, L. C., \& Razavieh, A. (2002). Introduction to research in education. Sixth Edition. USA : Wadsworth Group.

5. Azizi Yahaya, Shahrin Hashim, Jamaludin Ramli, Yusof Boon \& Abdul Rahim Hamdan (2007). Menguasai penyelidikan dalam pendidikan: Teori, analisis \& interpretasi data. PTS: Kuala Lumpur.

6. Che Nidzam Che Ahmad (2011). Aspek-aspek fizikal dan psikososial dalam persekitaran pembelajaran makmal sains. Tesis doktor falsafah yang tidak diterbitkan, Universiti Kebangsaan Malaysia.

7. Che Nidzam Che Ahmad, Kamisah Osman \& Lilia Halim (2010). Hubungan Ramalan Persekitaran Pembelajaran Makmal Sains dengan Tahap Kepuasan Pelajar. Jurnal Pendidikan Malaysia, 35(2), 19-30.

8. Creswell, J. W. (2009). Research design: Qualitative, quantitative and mixed methods approaches. Los Angeles: Sege.

9. Creswell, J. W. (2012). Educational research: Planning, conducting and evaluating quantitative and qualitative research, (4th ed.). Boston: Pearson.

10. Creswell, J. W. (2014). Educational research: Planning, conducting and evaluating quantitative and qualitative research, (4th ed.). Pearson new international edition. Harlow, Essex: Pearson Education Limited.

11. Fauzi Hussin, Jamal Ali \& Mohd Saifoul Zamzuri Noor (2014). Kaedah penyelidikan \& analisis data SPSS. Sintok: Universiti Utara Malaysia.

12. Hofstein, A., Dkeidek, I., Katchevitch, D., Nahum, T. L., Kipnis, M., Navon, O., Shore, R., Taitelbaum, D. \& Mamlok-Naaman, R. (2019) Research on and development of inquiry-type chemistry laboratories in Israel. Israel Journal of Chemistry, 59, 514-523.

13. Kementerian Pendidikan Malaysia (2012). Pelan Pembangunan Pendidikan Malaysia 2013 - 2025. Putrajaya: Kementerian Pendidikan Malaysia.

14. Kementerian Pendidikan Malaysia (2014). Kemahiran Berfikir Aras Tinggi aplikasi di sekolah. Putrajaya: Bahagian Pembangunan Kurikulum.

15. Kementerian Pendidikan Malaysia (2016). Dokumen Standard Kurikulum Dan Pentaksiran Sains Tingkatan 2. Putrajaya: Bahagian Pembangunan Kurikulum.

16. Kementerian Pendidikan Malaysia (2016). Pembelajaran abad ke-21. Putrajaya: Kementerian Pendidikan Malaysia.

17. Kementerian Pendidikan Malaysia (2018). Kertas Soalan Peperiksaan Sebenar PT3 2016 dan 2017. Selangor: Pustaka Yakin Pelajar Sdn. Bhd.

18. Kiong, T., T., Jailani Md Yunos, Razali Hassan, Heong, Y., M., Atan Hj. Hussein, \& Mimi Mohaffyza Mohamad (2012). Thinking skills for secondary school students in Malaysia. Journal of Research, Policy \& Practice of Teachers \& Teacher Education, 2 (2). 12-23.

19. Madhuri, G., V., Kantamreddi, V., S., S., N. \& Prakash Goteti, L., N., S. (2012). Promoting higher order thinking skills using inquiry-based learning. European Journal Of Engineering Education, 37(2), 117-123.

20. Mazlini Adnan, Aminah Ayob, Ong Eng Tek, O., E., Mohd Nasir Ibrahim, Noriah Ishak \& Jameyah Sheriff (2016). Memperkasa pembangunan modal insan malaysia di peringkat kanakkanak: Kajian kebolehlaksanaan dan kebolehintegrasian pendidikan STEM dalam kurikulum PERMATA negara. Malaysian Journal of Society and Space, 12(1), 29-36.

21. Mubarok, Suprapto, \& Adam (2018). Using inquiry-based laboratory to improve students' higher order thinking skills (HOTs). Journal of Physics: $\quad$ Conference Series. 1171 (1), 1-5. doi:10.1088/1742-6596/1171/1/012040.

22. Nunnally, J. (1978). Psychometric theory. McGraw-Hill, New York, NY.

23. Nur Hawa Hanis Abdullah \& Ghazali Darusalam (2018). Kesediaan guru melaksanakan kemahiran berfikir aras tinggi dalam pengajaran. Jurnal Kurikulum \& Pengajaran Asia Pasifik, 6(3), 22-31.

24. Nur Liyana Ali, Ta, G., C., Sharifah Zarina Syed Zakaria, Mazlin Mokhtar \& Sharina Abdul Halim (2014). Pembangunan satu pendekatan bagi memperkasakan sistem keselamatan makmal sains sekolah di malaysia. Jurnal Pendidikan Malaysia, 39(2), 153-160.

25. Pyatt, K. \& Sim, R. (2007). Learner performance and attitudes in tradional versus simulated laboratory experiences. Proceedings ascilite Singapore 2007: Full paper: Pyatt and Sims, 870-879.

Published By:

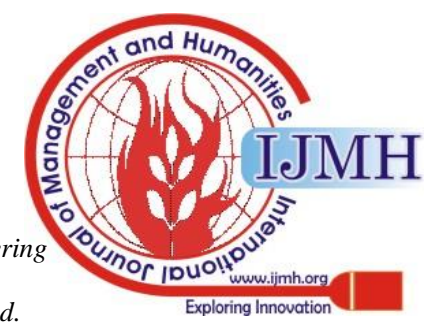


26. Ramnarain, U. \& Hlatswayo, M. (2018). Teacher beliefs and attitudes about inquiry-based learning in a rural school district in South Africa. South African Journal of Education, 38(1), 1-10. doi.org/10.15700/saje.v38n1a1431.

27. Saipolbarin Ramli, Muhammad Taufiq Abdul Ghani, Nazri Atoh \& Taj Rijal Muhammad Romli (2019). Integrasi elemen kemahiran berfikir aras tinggi (KBAT) berasaskan kit media dalam amalan pembelajaran dan pemudahcaraan guru pelatih bahasa arab. International Journal of Language Education and Applied Linguistics (IJLEAL), 09(1), 33-44.

28. Shahril Sabudin, Azlin Norhaini Mansor, Subahan Mohd. Meerah \& Azliza Muhammad (2018). Teacher-level factors that influence students' science and technology culture: HLM analysis. International Journal of Academic Research in Business and Social Sciences, 8(5), 978-985.

29. Stanger-Hall, K., F. (2012). Multiple-choice exams: an obstacle for higher-level thinking in introductory science classes. CBE-Life Sciences Education, 11, 294-306.

30. Wayan Redhana (2019). Mengembangkan keterampilan abad ke-21 dalam pembelajaran kimia. Jurnal Inovasi Pendidikan Kimia, 13(1), $2239-2253$

\section{AUTHORS PROFILE}

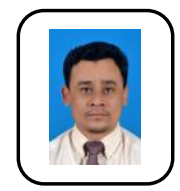

Mohd Saifulkhair Omar, is currently pursuing Ph.D (Education) in the School of Education and Modern Languages, College of Arts and Sciences (CAS), Universiti Utara Malaysia. Graduated first degree from the University of Technology Malaysia (UTM) with a Bachelor of Engineering (Hons) in Chemical Engineering and Postgraduate Diploma in Education (Science) at Institut Pendidikan Guru (IPG) Keningau Campus, Sabah . Then, pursuing a second degree in Master of Science (M.Sc) in Education Management at University Utara Malaysia (UUM).

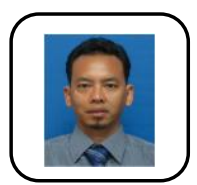

Mohd Isha Awang, is a Associate Professor in the School of Education and Modern Languages, College of Arts and Sciences (CAS), Universiti Utara Malaysia. Graduated first degree from the University of Malaya with a Bachelor of Arts (Hons) in Malay Language Studies. Then, pursuing a second degree in Master of Education (M.Ed) in Language Education. In 2009, awarded the Doctor of Philosophy degree in Testing and Measurement from the University of Malaya. Since serving at Universiti Utara Malaysia from 1999, I was awarded the Anugerah Perkhidmatan Cemerlang (APC) twice. I have published several books and articles in the journals related to educational assessment and Malay language. In terms of research, I was involved with studies funded by UUM and FRGS grant and also from the Ministry of Education. The focus of my research focuses on 'Educational Assessment', 'Teacher Quality' and 'Language Education'. Until now I have won the Innovation, Research and Publications Group LEAD Award in 2012. I have been appointed and recognized as Munsyi Dewan by Dewan Bahasa dan Pustaka. I am frequently invited as a speaker to gives lectures and conduct workshops related to test items construction and Malay grammatical by various parties either in UUM or others public sector. I have mastered to analyze data using GENOVA (Generalizability Theory), Quest, Winsteps (Item Response Theory) and AMOS. I was appointed as Subject Matter Expert at OUM on 2007. In addition I also experienced as assessor for GEMA online Journal, Journal of Pendidikan Bahasa Melayu and Journal of Education, published by the UKM, and a members of the Advisory Board Committee of The Council of Education Dean Journal and a members of The Council of Education Dean IPTA in 2010.

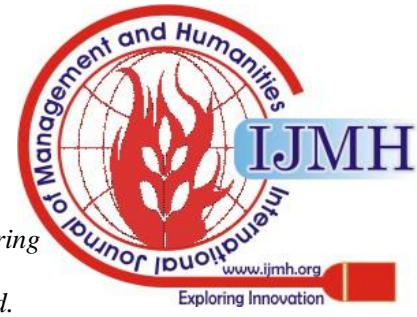

